Al-Bayyinah: Journal of Islamic Law-ISSN: 1979-7486 (p); 2580-5088 (e) Volume VI Number 1, pp. 31-42

\title{
PEMBERDAYAAN YURISPRUDENSI SEBAGAI HUKUM ISLAM (Analisis Fungsional dalam Rangka Optimalisasi Kinerja Hakim Agama)
}

\section{A. Jasmani}

(Dosen Tetap STAIN Watampone, Sulawesi Selatan, Indonesia, email: andijasmani.iainbone@gmail.com

\section{Abstract}

Religion judge is one of human service for justice seeker through religion judicature. These is one principle that religion judge as other judges cannot refuse lawsuit with unarranged reason by the law.

In doing the principle above, jurisdiction has an important role. This is caused by the cases which have the similarities. The fact shows that the laws cannot cover all cases well because of article faktor which is interpretative or the case is new one from this fact, religion judge has to have broad knowledge about jurisdiction. That's the cause that jurisdiction is admitted as one of the important law source in judicature world.

Kata Kunci: Yurisprudensi, Hakim Agama, Pemberdayaan, Analisis Fungsional.

\section{PENDAHULUAN}

\section{A. Latar Belakang}

Secara ideologi, syari'at Islam (hukum Islam) harus melekat pada segi-segi kehidupan tiap pribadi muslim, kapan dan dimana saja. Idealisme universalistik syari'at Islam ini ternyata tidak demikian ditengah-tengah komunitas muslim. Banyak faktor yang menyebabkan hal itu, diantaranya adalah sistem politik (pemerintah).

Indonesia sebagai sebuah Negara, ternyata memberikan ruang bagi berlakunya syari'at Islam (Pasal 29 ayat 1 UUD 
1945). Kendati demikian, efektivitas berlakunya syari'at Islam belum maksimal. Salah satu faktor yang menentukan adalah keseriusan pemerintah dalam menempatkan syari'at Islam (hukum Islam) sebagai salah satu sumber pembentukan hukum Nasional.

Indonesia sebagai Negara Hukum (Rechstaat), telah memberi tempat tersendiri mengenai posisi dan peran syari'at Islam dalam mengayomi pencari keadilan. Dalam posisinya sebagai sumber hukum nasional, keberadaan dan peranannya sangat ditentukan oleh pribadi-pribadi umat Islam sendiri, dan yang tidak kalah pentingnya adalah pemerintah dan penegak hukum.

Hingga saat ini, penerapan hukum Islam bagi komunitas muslim Indonesia masih terbatas pada aspek ibadah, hukum kekeluargaan, dan sedikit hukum ekonomi syari'ah. Salah satu institusi yang diberi amanah memaksimalkan operasionalisasi hukum Islam di Indonesia adalah Peradilan Agama. Berbicara tentang peradilan agama itu sendiri, salah satu komponen yang tersentuh paling depan adalah hakim-hakim agama.

Menyoal tentang hakim-hakim agama dalam kaitan keberadaannya dengan syari'at Islam di Indonesia, maka yang dituntut dari mereka adalah kemampuannya menyelesaikan semua perkara yang diajukan kepadanya, tidak terkecuali yang bersifat luar biasa dan kasuistik. Untuk kinerja hakim agama tersebut, hal yang tidak kalah pentingnya adalah kemampuan hukum materil dan formal memenuhi kasus-kasus yang diajukan kepada peradilan agama mulai dari tingkat bawah sampai ke Mahkamah Agung.

Tampaknya, tuntasnya jenis-jenis kasus yang masuk pada Pengadilan Agama tidak dapat dijamin, begitu juga hukum acara, yang sewaktu-waktu tidak dapat mengakomodir prosedur penyelesaian kasus-kasus tertentu. Dengan demikian yurisprudensi merupakan alternative rujukan bagi para hakim agama di Pengadilan Agama.

\section{B. Rumusan Masalah}

Pada uraian latar belakang masalah diatas, beberapa hal penting yang berkaitan dengan pemberdayaan yurisprudensi dalam upaya optimalisasi kinerja hakim agama telah tampak 
jelas. Hal-hal yang dimaksud adalah (1) Kemutlakan bagi hakim-hakim agama menyelesaikan tiap kasus yang diajukan kepadanya; (2) Adanya keterbatasan hukum materil dan formil dalam menyelesaikan kasus perkara; (3) Adanya kemutlakan hakim-hakim agama menafsirkan hukum-hukum materil dan formil yang pada gilirannya dapat memunculkan yurisprudensi; (4) Adanya kejelasan kewenangan dan kompetensi peradilan agama yang pada gilirannya menempatkan yurisprudensi sebagai sumber hukum Islam.

Mengacu pada identifikasi permasalahan diatas, masalah pokok yang dikaji dalam tulisan ini adalah bagaimana urgensi yurisprudensi pasca Inpres No. 1 Tahun 1991 serta pasca UU No. 7 Tahun 1989?

\section{Kajian Pustaka}

Dalam kaitannya dengan penyelesaian kasus (perkara), istilah "yurisprudensi" lebih dikenal oleh para hakim agama sebagai kumpulan keputusan Mahkamah Agung (dan Pengadilan Tinggi Agama) mengenai perkara tertentu berdasarkan pertimbangan hakim sendiri yang dipedomani oleh hakim lain dalam memutuskan perkara yang sama atau hampir sama. ${ }^{1}$

Berdasarkan pengertian yurisprudensi di atas diketahui bahwa substansinya adalah putusan hakim diluar yang biasa. Yang biasa itu adalah putusan hakim yang persis memenuhi unsur-unsur pasal hukum materil maupun hukum formil. Yang luar biasa adalah segala putusan hakim yang secara kenyataan seluruh unsur-unsurnya tidak terakomodir oleh hukum materil maupun formil sehingga hakim perlu melakukan penafsiran hukum beracara itu sedemikian rupa. Dari sisi lahirlah sebuah putusan hakim atas suatu kasus tertentu.

Dari keyakinan munculnya yurisprudensi dapat dinyatakan bahwa para hakim, tidak terkecuali hakim-hakim agama perlu memiliki ilmu yang luas dalam menerapkan pasal. Hal ini dibutuhkan agar tugas pokok hakim itu tak terabaikan. Peluang untuk mengembangkan pemikiran di bidang hukum Islam, terutama bagi para hakim agama sesuai dengan petunjuk

Mohammad Daud Ali, "Pengembangan Hukum Islam dan Yurisprudensi Peradilan Agama”, Mimbar Hukum, No.12, 1994, h.18-19. 
Undang-undang No. 7 Tahun 1989 pasal 56 (1) yang menyatakan bahwa pengadilan tidak boleh menolak untuk memeriksa dan memutuskan suatu perkara yang diajukan kepadanya dengan dalih bahwa hukum tidak jelas, melainkan wajib memeriksa dan memutuskannya. ${ }^{2}$ Sebagai penegak hukum, adalah sangat penting bagi hakim memperhatikan kesadaran hukum masyarakat yaitu Undang-undang No. 14 Tahun 1970 pasal 27 (1) yang menyatakan "Hakim sebagai penegak hukum dan keadilan wajib menggali, mengikuti dan memahami nilai-nilai hukum yang hidup dalam masyarakat". ${ }^{3}$ Hal ini sesuai dengan qaidah fiqhiyyah yang menyatakan:

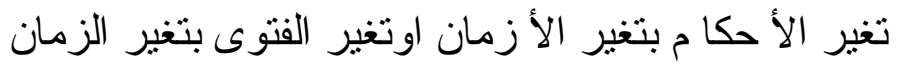

Artinya: Perubahan hukum dan fatwa akibat berubahnya zaman.

Menurut Daud Ali, ${ }^{4}$ hakim dianggap tahu hukum, tidak dibenarkan menolak memeriksa dan mengadili suatu perkara yang diajukan kepadanya dengan dalih bahwa hukumnya tidak ada atau kurang jelas.

Kendatipun yurisprudensi itu adalah sebuah penafsiran hakim, namun dalam dunia hukum ia telah diakui sebagai salah satu sumber hukum, ${ }^{5}$ menurut Sudikno yang mengutip ulasan dari Ahmad Sanoesi, sumber hukum itu terbagi atas sumber hukum normal yang langsung dan sumber hukum normal yang tidak langsung.

Sumber hukum normal yang langsung atas pengakuan undang-undang yaitu: (1) undang-undang; (2) perjanjian antar Negara; (3) kebiasaan. Sedangkan sumber hukum normal yang

${ }^{2}$ Mahkamah Agung Republik Indonesia, Undang-Undang Republik Indonesia No. 3 Tahun 2006 tentang Perubahan Atas Undang-Undang No. 7 Tahun 1989 tentang Peradilan Agama, Direktorat Jenderal Badan Peradilan Agama, 2006, h.63-64.

Abdul Gani Abdullah, Himpunan Perundang-Undangan dan Peraturan Peradilan Agama, Jakarta: Intermasa, 1991, h.174.

${ }^{4}$ Wahbah al-Zuhailiy, Ushul Fiqh al-Islamiy, Juz. I, Damaskus: Dar al-Fikr, 1986, h.651.

5 Mohammad Daud Ali, "Pengembangan Hukum Islam dan Yurisprudensi Peradilan Agama”, Mimbar Hukum, No. 12, 1994, h.20. 
tak langsung atas pengakuan Undang-Undang yaitu: (1) perjanjian; (2) doktrin; (3) yurisprudensi termasuk pada peradilan Agama. Oleh sebab itu, peradilan Agama dipastikan telah memiliki yurisprudensi yang meliputi kompetensinya, terutama sebelum diterbitkannya hukum materil dan formil peradilan Agama. Sebuah hasil penelitian tentang yurisprudensi peradilan Agama antara tahun 1958-1985 (sebelum terbitnya UU Peradilan Agama dan Kompilasi Hukum Islam Indonesia) oleh sebuah tim, untuk itu telah berhasil menghimpun 16 putusan tentang perkawinan yang meliput: (1) izin kawin; (2) izin poligami; (3) pembatalan nikah; (4) pengesahan nikah; (5) fasid nikah; (6) mahar; (7) mas kawin; (8) syiqaq; (9) fasakh; (10) pembatalan dan pengesahan talak; (11) gugat cerai dan cerai talak; (12) nafkah; (13) harta bersama; (14) taklik talak; (15) hadanah; (16) rujuk. ${ }^{6}$

Selain substansi yurisprudensi, yang tidak kalah pentingnya diketahui adalah adanya kecenderungan seorang hakim mengikuti pendapat hakim yang lain dalam memutus perkara. Sebab kewajaran itu adalah adanya jenjang peradilan yang pada gilirannya menuntut perbedaan kualifikasi hakim itu sendiri. Peradilan Agama seperti halnya lembaga peradilan lainnya merupakan lembaga peradilan berjenjang, yaitu Pengadilan Agama di tingkat pertama, Pengadilan Tinggi Agama di tingkat banding dan Mahkamah Agung ditingkat kasasi. Oleh sebab itu, hakim-hakim tinggi pada Pengadilan Tinggi Agama dan hakim-hakim agung pada Mahkamah Agung, secara teoritik dan idealistic, memiliki wawasan profesionalisme yang lebih dari hakim-hakim agama di bawahnya. Daud Ali merinci beberapa alasan tentang yurisprudensi sebagai sumber/dasar memutus perkara bagi hakim yaitu (1) Putusan hakim itu mengikat (terutama putusan Pengadilan Tinggi dan Mahkamah Agung); (2) Faktor psikologi dan praktis; (3) kesesuaian pendapat seorang hakim akan yurisprudensi. ${ }^{7}$

\section{Metode Penelitian}

Sesuai dengan judul penelitian ini, maka dinyatakan bahwa orientasi penelitian ini adalah uraian teoritis tentang

\footnotetext{
${ }^{6}$ Muhammad Daud Ali, Loc. Cit

${ }^{7}$ Ibid, h. 19 .
} 
fungsi dan peranan yurisprudensi bagi hakim agama di lembaga peradilan agama dalam menangani perkara yang diajukan kepadanya. Berdasarkan hal itu, data penelitian ini seluruhnya bersumber dari literature. Oleh sebab itu penelitian ini adalah penelitian kepustakaan (Library Research).

Semua data yang relevan dengan penelitian ini, sesuai dengan jenis penelitian ini, diolah secara kualitatif dan disajikan dengan alur piker deduktif. Penelitian ini menampilkan data dari sumber-sumber terjangkau, beberapa ulasan dan pernyataan yang pada gilirannya memuat kesimpulan dan rekomendasi penelitian.

\section{PEMBAHASAN}

A. Urgensi Yurisprudensi dalam Peningkatan Kinerja Hakim-Hakim Agama Pasca Inpres No. 1 Tahun 1991 dan UU No. 7 Tahun 1989

Hingga saat ini para ahli hukum, tetap memiliki kesamaan pendapat bahwa yurisprudensi adalah sumber hukum yang cukup penting peranannya dalam dunia peradilan, tidak terkecuali peradilan agama. Kalau dilihat dari sudut fiqih qadha' (peradilan), yurisprudensi dikenal sebagai salah satu sumber hukum Islam. Wadahnya adalah adanya keharusan hakim berijtihad bila aturan (hukum) suatu kasus tidak ditemukan secara jelas. Yurisprudensi atas dasar kesamaan kasus dengan putusan hakim yang telah memiliki kekuatan tetap merupakan penjabaran qiyas. Itulah salah satu butir Risalat al-Qada' Umar bin Khattab kepada para hakim ketika itu. ${ }^{8}$

Setelah melihat bagaimana legitimasi hukum Islam terhadap yurisprudensi itu, maka ada baiknya jika dilihat urgensinya bagi peningkatan kinerja para hakim agama. Uraian ini terutama urgensi yurisprudensi setelah lahirnya Kompilasi Hukum Islam dan UU No. 7 Tahun 1989. Kompilasi Hukum Islam, berdasarkan Inpres No. 1 Tahun 1991 merupakan hukum materil peradilan agama di Indonesia, sedangkan UU No. 7 Tahun 1989 adalah hukum formil tentang prosedur dan aturanaturan tertulis beracara. Keduanya sebagai pedoman bagi para

${ }^{8}$ Hasbi Ash-Siddieqy, Sejarah Peradilan Islam. (Cet. ketiga, Jakarta: Bulan Bintang, 1970), h.27 
hakim agama, baik ditingkat Pengadilan Agama maupun Pengadilan Tinggi Agama,

Instruksi Presiden No. 1 Tahun 1991 memerintahkan Menteri Agama untuk menyebarluaskan Kompilasi Hukum Islam untuk digunakan oleh instansi pemerintah dan masyarakat yang memerlukannya. Menteri Agama telah menindaklanjuti Inpres tersebut melalui Keputusan Menteri Agama No. 154 Tahun 1991 tentang Pelaksanaan Instruksi Presiden No. 1 Tahun 1991 tersebut. ${ }^{9}$ Bagaimana penerapannya di lingkungan peradilan agama. Direktorat Peradilan Agama melakukan monitoring dengan bekerja sama pihak tertentu melalui Anggaran Tahun 2012, 2013, dan 2014. Penelitian dilakukan terhadap 1008 putusan PA dan PTA tahun 2009, 2000 yang diambil secara acak dari 46 PA dan 6 PTA (Jakarta, Bandung, Serang, Yogyakarta, Surabaya dan Bandar Lampung). ${ }^{10}$

Hasil monitoring Direktorat Peradilan Agama menunjukkan bahwa putusan PA dan PTA menggunakan materi Kompilasi Hukum Islam. Secara eksplisit dapat diterangkan bahwa dari 1008 putusan, 715 putusan menggunakan Kompilasi Hukum Islam dan 293 putusan tidak menggunakannya. ${ }^{11}$

Hasil penelitian lain menunjukkan bahwa jumlah putusan PTA (Jakarta, Bandung, Yogyakarta, Surabaya) yang tidak menggunakan Kompilasi Hukum Islam lebih banyak dari jumlah putusan PTA yang menggunakan Kompilasi Hukum Islam. Sementara jumlah putusan PA yang tidak menggunakan Kompilasi Hukum Islam lebih sedikit dari jumlah PA yang menggunakannya. $^{12}$

Mengacu pada pengertian yurisprudensi dan banyaknya putusan Pengadilan Tinggi Agama tidak berdasar pada Kompilasi Hukum Islam, maka urgensi yurisprudensi telah tampak ke permukaan. Artinya, para hakim agama telah melaksanakan kompetensi absolutnya sebagaimana yang diatur dalam UU No. 14 Tahun 1970 dan UU No. 7 Tahun 1989. Menurut Muchtar Zarkasy, SH, tidak digunakannya Kompilasi

${ }^{9}$ H. Muchtar Zarkasyi, SH, “Aktualisasi Kompilasi Hukum Islam dan Upaya Menjadikannya sebagai Undang-Undang”, Makalah, h.2.

${ }^{10}$ Ibid.

11 Ibid.

${ }^{12}$ Ibid., h.3. 
Hukum Islam memutus perkara ada beberapa kemungkinan penyebabnya yaitu:

1. Hakim tidak memiliki kepedulian terhadap Kompilasi Hukum Islam.

2. Hakim memiliki kepedulian terhadap Kompilasi Hukum Islam tetapi tidak menggunakannya.

3. Hakim tidak merasa ada keharusan untuk menggunakan Kompilasi Hukum Islam. ${ }^{13}$

Menurut hemat penulis, ketiga alasan tersebut di atas memang ada kemungkinannya dianut (dilakukan) oleh hakimhakim Pengadilan Tinggi Agama. Indikator yang digunakan adalah hasil penelitian tentang pendapat hakim agama tentang penggunaan Kompilasi Hukum Islam sebagai landasan hukum sebagai berikut: ${ }^{14}$

a. Mereka yang menyatakan tidak pernah menggunakan Kompilasi Hukum Islam sebanyak 5,88\% (3 orang).

b. Mereka yang menyatakan kadang-kadang menggunakan Kompilasi Hukum Islam sebanyak 39,24\% (14 orang).

c. Mereka yang selalu menggunakan Kompilasi Hukum Islam sebanyak 52,96\% (27 orang).

d. Yang tidak menjawab sebanyak 1,96\% (1 orang).

Berdasarkan hasil penelitian diatas, ternyata hakim yang tidak memakai Kompilasi Hukum Islam sebagai hukum (materil) cukup signifikan juga. Dengan demikian, mereka terlalu longgar dalam pemikiran berijtihad yang pada gilirannya memperkaya yurisprudensi peradilan agama.

\section{B. Hakim Agama Setelah Terbitnya Undang-Undang No. 3 Tahun 2006}

Peradilan agama sebagai salah satu tumpuan muslim Indonesia dalam mencari keadaan terus berbenah diri. Satu momentum penting adalah digabungkannya lembaga peradilan agama ke Mahkamah Agung. Secara yuridis, hal itu mengacu pada terbitnya Undang-Undang No. 3 Tahun 2006 tentang Perubahan Undang-Undang No. 7 Tahun 1989 tentang Peradilan Agama.

\footnotetext{
${ }^{13}$ Ibid.

${ }^{14}$ Amir bin Mu'allim, Op.Cit., h.33.
} 
Konsekuensi logis akibat terbitnya Undang-Undang No. 3 Tahun 2006 adalah terjadinya sejumlah perubahan ditubuh peradilan agama. Misalnya, pasal 5 ayat 1 menegaskan: "Pembinaan teknis peradilan, organisasi, administrasi dan finansial pengadilan dilakukan oleh Mahkamah Agung". ${ }^{15}$ Demikian juga halnya dengan kompetensi absolute hakim agama sebagaimana tertuang dalam pasal 49: Pengadilan Agama bertugas dan berwenang memeriksa dan memutus perkara di tingkat pertama antara orang-orang yang beragama Islam di bidang: perkawinan, waris, wasiat, hibah, wakaf, zakat, infaq, sadaqah dan ekonomi syariah. ${ }^{16}$

Dengan pembinaan teknis peradilan agama dan kompetensi absolute hakim agama yang tertuang dalam UndangUndang Nomor 3 tahun 2006 tersebut adalah fakta wajah baru dinamika peradilan agama tentunya. Bagaimana dengan yurisprudensi?

Yurisprudensi sebagai pendapat hukum para yuris (hakim) adalah perwujudan kebebasan dalam menemukan kebenaran yang berkeadilan. Dengan esensi kebebasan tersebut, pasal 5 ayat 2 Undang-Undang Nomor 3 Tahun 2006 mengakomodir yurisprudensi itu. Ayat 2 pasal 5 berbunyi: "Pembinaan sebagaimana dimaksud pada ayat (1) tidak boleh mengurangi kebebasan hakim dalam memeriksa dan memutus perkara. ${ }^{17}$

Dengan mengacu pada data banyaknya putusan hakim Pengadilan Tinggi Agama yang tidak mengacu pada Kompilasi Hukum Islam (KHI), dan adanya asas kebebasan hakim agama dalam memutus perkara yang menjadi kompetensinya sesuai pasal 49 telah memberikan keyakinan betapa pentingnya yurisprudensi sebagai rujukan hakim agama dalam memutus perkara hingga saat ini.

Satu hal yang sangat membuka signifikansi yurisprudensi bagi hakim agama adalah munculnya satu kompetensi absolut baru hakim agama, yaitu ekonomi syari'ah. Betapa tidak, kemampuan hakim-hakim agama yang umumnya belum memahami ekonomi syari'ah secara terperinci dapat

\footnotetext{
${ }^{15}$ Mahkamah Agung RI, op.cit., h.4

${ }^{16}$ Ibid., h.20.

${ }^{17}$ Mahkamah Agung RI, loc. cit.
} 
memunculkan keputusan yang berbeda atas kasus yang sama. Dengan demikian pencari keadilan sangat berpotensi melakukan upaya hukum banding di Pengadilan Tinggi Agama, bahkan kasasi di Mahkamah Agung. Dengan potensi seperti itu, hakim Pengadilan Tinggi Agama, khususnya hakim agama Mahkamah Agung tertantang untuk lebih professional dengan kompetensi absolute baru tersebut. Akhirnya nanti akan muncul banyak putusan hakim Pengadilan Tinggi Agama dan Mahkamah Agung tentang ekonomi syari'ah sebagai yurisprudensi. Betapa tidak, materi-materi ekonomi syari'ah adalah tergolong hal baru. Dalam penjelasan pasal 49 Undang-undang Nomor 3 Tahun 2006 dinyatakan bahwa yang dimaksud ekonomi syari'ah adalah: bank syari'ah, lembaga keuangan mikro syari'ah, asuransi syari'ah, reasuransi syari'ah, reksadana syari'ah, obligasi syari'ah dan surat berharga berjangka menengah syari'ah, sekuritas syari'ah, pembiayaan syari'ah, pegadaian syari'ah, dana pension lembaga keuangan syari'ah, bisnis syari'ah. ${ }^{18}$

Di samping kompetensi absolut baru hakim agama tersebut, yang tidak kalah pentingnya memicu putusan hakim yang tegas tidak mengacu pada hukum materil peradilan agama (KHI) adalah kompleksitas kehidupan modern. Sebagai contoh adalah terbitnya putusan hakim Pengadilan Agama Jakarta Pusat tentang sita jaminan harta gonogini antara Halimah dan Bambang Trihatmojo. Putusan semacam itu adalah tidak ditemukan secara eksplisit dalam pasal pengaturan harta bersama Komplikasi Hukum Islam (HKI). Putusan itu berpotensi munculnya upaya hukum banding dan kasasi bagi tergugat yang pada gilirannya melahirkan sebuah putusan yang dapat dijadikan sebagai yurisprudensi atas kasus yang serupa di kemudian hari.

\section{PENUTUP}

\section{A. Simpulan}

Berdasarkan data dan analisis data yang dilakukan oleh penulis ternyata menunjukkan bahwa putusan hakim Pengadilan Agama tidaklah seluruhnya diakomodir oleh Kompilasi Hukum

${ }^{18}$ Ibid., h.38 
Islam dan UU No. 7 Tahun 1989. Dengan demikian dapat disimpulkan bahwa kinerja hakim Pengadilan Agama sangat terbantu oleh legalitas yurisprudensi sebagai pengembangan sumber-sumber hukum yang dipedomani oleh hakim-hakim Pengadilan Agama sebagaimana amanat pasal 5 ayat 2 UndangUndang Nomor 3 Tahun 2006 tentang Perubahan UndangUndang Nomor 7 Tahun 1989 tentang Peradilan Agama.

\section{B. Saran}

Berkaitan dengan kesimpulan diatas dapat pula diajukan rekomendasi agar pengetahuan dan tingkat pendidikan hakimhakim agama lebih ditingkatkan. Dengan demikian kemampuan dan profesionalitas hakim-hakim agama dapat tercapai sehingga segala kasus dapat diputuskan tanpa kendala yang berarti. 


\section{DAFTAR PUSTAKA}

Abdullah, Abdul Gani. Himpunan Perundang-undangan dan Peraturan Peradilan Agama, Jakarta: Intermasa, 1991.

Ali, Mohammad Daud, "Pengembangan Hukum Islam dan Yurisprudensi Peradilan Agama”, Mimbar Hukum, No.12 Tahun 1994.

Mahkamah Agung Republik Indonesia, Undang-undang Republik Indonesia No. 3 Tahun 2006 tentang Perubahan Atas Undang-Undang No. 7 Tahun 1989 tentang Peradilan Agama, Direktorat Jenderal Badan Peradilan Agama, 2006.

Mu'allim, Amir bin, MA, Prof. Yurisprudensi Peradilan Agama; Cetakan Pertama. Jakarta; Badan Litbang dan Diklat Departemen Agama RI, 2006.

Ash-Siddieqy, Hasbi. Sejarah Peradilan Islam. Cetakan III, Jakarta: Bulan Bintang, 1970.

Zarkasyi, Muchtar SH. "Aktualisasi Kompilasi Hukum Islam dan Upaya Menjadikannya sebagai Undang-Undang”, Makalah.

al-Zuhailiy, Wahbah. Ushul Fiqh al-Islamiy, Juz. I, Damaskus: Dar al-Fikr, 1986. 